\title{
DESIGNING A VACCINE FOR CANCER: A LOOK INTO DENDRITIC CELL CANCER VACCINE
}

\section{PRAVEEN KUMAR VEMURI ${ }^{1 *}$, ANKITHA KUNTA ${ }^{1}$, RISHITHA CHALLAGULLA ${ }^{1}$, ELIZABETH ANWITHA JOSE ${ }^{1}$, VIJAYA LAKSHMI BODIGA ${ }^{2}$}

${ }^{1}$ Department of Biotechnology, Centre for Genomics and Proteomics, Koneru Lakshmaiah Education Foundation, Vaddeswaram, Andhra Pradesh, India. ${ }^{2}$ Department of Molecular Biology, Institute of Genetics and Hospital for Genetic Diseases, Osmania University, Hyderabad, Telangana, India. Email: vemuripraveen@kluniversity.in

Received: 02 April 2019, Revised and Accepted: 05 May 2019

\begin{abstract}
The fundamental premise behind clinical approaches for dendritic cell-mediated immunization in cancer is that the limiting defect in natural antitumor immunity is at the level of antigen presentation. In contrast to vaccines for the prevention of infections, cancer vaccines are administered in a therapeutic mode, to eradicate antigen-bearing tumor cells already present in the host. Over the decades, the identification of antigens that can serve as targets for immune effectors has resulted in a profusion of strategies for activating tumor antigen-specific immune responses. Therapeutic vaccines, unlike prophylactic vaccines for the prevention of infections, all share some basic attributes, the presence of target antigens, and a method for delivering the antigen into the antigen-presentation machinery in conjunction with other molecules required to provide T-and/or B-cell activation.
\end{abstract}

Keywords: Cancer, Vaccine, Dendritic cell, Antigen presenting cells, Tumor, Immunity.

(C) 2019 The Authors. Published by Innovare Academic Sciences Pvt Ltd. This is an open access article under the CC BY license (http://creativecommons. org/licenses/by/4. 0/) DOI: http://dx.doi.org/10.22159/ajpcr.2019.v12i6.33374

\section{INTRODUCTION}

Dendritic cells (DCs) are potent antigen-presenting cells (APC's) [1], roles of APC in the body are to ingest [2], digest [3], and present antigens to other cells of the immune system [4]. Presentation of antigens to white blood cells is a crucial step in the development of an adaptive immune response [5]; it activates "naïve" [6] or "inert" T cells [7] whose $\mathrm{T}$ cell receptor is specific for the particular antigen being presented by the APC [8]. The cytotoxic T lymphocyte (killer T cell) adaptive immune response is the principle way in which tumors can be destroyed by the body [9]. Targeting tumor antigens to DCs, either ex vivo or in vivo [10], therefore, allow an opportunity to bypass these defects in antigen presentation [8], and take advantage of the many specialized features of DC as potent APC [9]. It has long been realized that many tumors are poorly immunogenic [10]. That is, if they are merely disaggregated and reinjected, they frequently grow unabated and do not activate a protective immune response [11]. The modified white blood cell injections can be used as a potential therapeutic vaccine against lethal diseases [12]. If successful, this vaccine will revolutionize the future of cancer treatment [13]. The DC cancer vaccine exploits the powerful antigen-presenting capacity of the DC and uses it to develop therapeutic immunity against cancer-associated antigens [14].

\section{MATURATION OF DCS AND IMMUNOTOLERANCE}

DCs are a class of bone-marrow-derived cells arising from lymphoid and myeloid hematopoiesis [15] that form an essential interface between innate sensing of pathogens and the activation of adaptive immunity [16]. Immature DCs are found in peripheral tissues and circulation [17]. The concentration of chemokine receptors is increased by the DCs on receiving the maturation signals [18]. This, in turn, increases the antigen presentation by major histocompatibility complex (MHC) molecules and aids in the amplification of T cell responses [19]. Further, additional danger signals are required by the DCs to turn them to activated form [20]. The maturation of DCs depends on the various types of signals for maturation (Fig. 1) [21]. The resultant mature phenotype affects $\mathrm{T}$ cell interaction and cytokine secretion [22]. Other than activation of the immune system, DCs can also produce immune tolerance, which can be used as a strategy for the production of a successful vaccine [23]. From the previous studies, it is known that immature DCs are more likely to exhibit tolerance [24]. Some other studies also suggest that immature or not fully mature DCs will not produce any desired effect in vaccination [25]. With the help of these studies, we can say that DC maturation is most essential to overcome immune tolerance and its barriers [26]. In particular, research on DCs has recently emerged as a fundamental aspect for the comprehension of the mechanisms underlying the pathogenesis of viral diseases, [27] as well as for the progress on the development of prophylactic and therapeutic vaccines [28]. In addition, the recent advances in DC biology have opened perspectives in the research on new adjuvants and novel strategies for the in vivo targeting of antigens to DCs, which are instrumental in the development of cancer vaccines [29].

\section{ANTIGEN PRESENTATION BY THE DCS}

After a DC has ingested and processed an antigen, it must communicate its finding to the rest of the immune system [30]. This may be achieved by physically bringing the pieces of the antigen to other immune cells [31]. However, since other cells do not have ready access to the engulfed particle inside the cell, the antigen fragment must be presented on the cell surface [32]. One of the ways this is achieved is through antigen binding to a special "presenting" molecule, MHC class I [33].

This allows the small morsel of antigen to be held in place on the cell surface and gives context to other immune cells, allowing them to respond properly [34]. Usually, proteins that APCs ingest (exogenous proteins) [35] are presented on MHC class II, not MHC class I; that is, MHC class I is reserved for fragments of proteins that cells produce themselves (endogenous proteins) [36]. However, APCs have a special ability to cross-present exogenous antigens on MHC class I, [37] which allows APCs to activate cells that can recognize tumor cells expressing tumor-specific antigens in the context of MHC class I [38].

\section{DEVELOPING AN IMMUNE RESPONSE}

After a DC has successfully presented an antigen bound to an MHC class I molecule on its cell surface, it migrates to a lymph node where many other white blood cells are waiting [36]. Here, DCs interact with CD8+T lymphocytes (Fig. 2) [37]. DC antigen/MHC class I complexes bind with $\mathrm{T}$ cell receptors on CD8+T lymphocytes [38]. This contact, 
in conjunction with other costimulatory and adhesive processes, causes CD8+T lymphocytes to multiply and mature into selective cellular perforin, commonly known as killer $\mathrm{T}$ cells (or cytotoxic $\mathrm{T}$ lymphocytes) [39]. These cells then migrate from the lymph node back into the blood and throughout the body in search of the antigen by which they were stimulated [40]. When they find cells that express the antigen presented with an MHC class I molecule, they destroy them [41]. Since cells normally present parts of their internal proteins on MHC class I molecules, cancer cells produce antigens can be recognized and destroyed in this way [42].

Most DC-based vaccines [43] are usually composed of the following four basic steps (Fig. 3).

1. Collect DCs.

2. Culture DCs in vitro.

3. Expose DCs to the cancer antigen(s) of your choice.

4. Administer the DCs into a patient as a vaccine.

\section{IMPROVING THE VACCINE}

At present, mild therapeutic effects of DC vaccines are available [44]. Scientists are now looking for new ways to increase this therapeutic effect. Some of the concepts and techniques that are being used to bring a curative vaccine for cancer closer to fruition are presented below [45].

\section{Gene transduction}

In addition to methods that apply the antigen to the DC directly, it is also possible to transfer the gene encoding the tumor-specific antigen into the DC (Fig. 4) [46]. Such an approach can be beneficial because it provides:

1. A continuous production of antigenic fragments

2. An intracellular source of antigen, easily accessible to the MHC class I pathway.

Continuous production of antigen allows for prolonged availability for loading into the MHC class I pathway [47]. Compared with peptidepulsing techniques that provide short-term exposure, antigen gene transduction provides long-term exposure [48]. Given that MHC class I/ antigen complexes are unstable and degrade relatively rapidly with time, it is believed helpful to have constant antigen present for continuous loading onto MHC class I. By providing an intracellular antigenic source; gene transduction improves the access of antigen fragments to the MHC class I pathway [49]. Exogenous antigen sources, as in peptide pulsing, are normally presented on the MHC class II pathway and require crosspresentation by the DC [50]. However, if the antigen is produced within the cell, it will be naturally loaded onto MHC class I without the need for the less-efficient cross-presentation process

To achieve gene transduction, viruses are normally used, [51] one of the most effective techniques for DC gene transduction [52] makes use of genetically modified adenoviruses [53]. The adenoviral vector boasts high transfection rates and allows for several vectors to be introduced into the same DC population [54]. In addition, this technique can also be used to transduce genes encoding immunostimulatory cytokines that stimulate the killer T lymphocyte response (cytotoxic T lymphocyte response) [55].

Gene technology can be united with DC cancer vaccine research; the results have been promising [56]. DC vaccine effectiveness could be increased by a combination of both antigen and immuno stimulatory cytokine gene transduction [57]. The cytokine interleukin 12 (IL-12) was chosen for the experiment due to its ability to activate immune cells and strengthen the killer T cell response in Mycobacterium tuberculosis [58]. Using adenoviral vectors, we can simultaneously introduce a breast cancer antigen (ErbB-2/neu) [59,60] and an IL-12 gene into DCs ex vivo before administering the vaccine (Fig. 5). The result was a significant strengthening of the protective and therapeutic immunity of mice against injected breast cancer cells [61].

Likewise, new natural $[62,63]$ and synthetic molecules $[64,65]$ capable of restoring and/or enhancing DC activities, often impaired in patients, have recently been identified and can be tested for their possible role in strategies of immunotherapy of cancer [66]. In addition to this, considerable interest has focused on the use of patients' DCs loaded

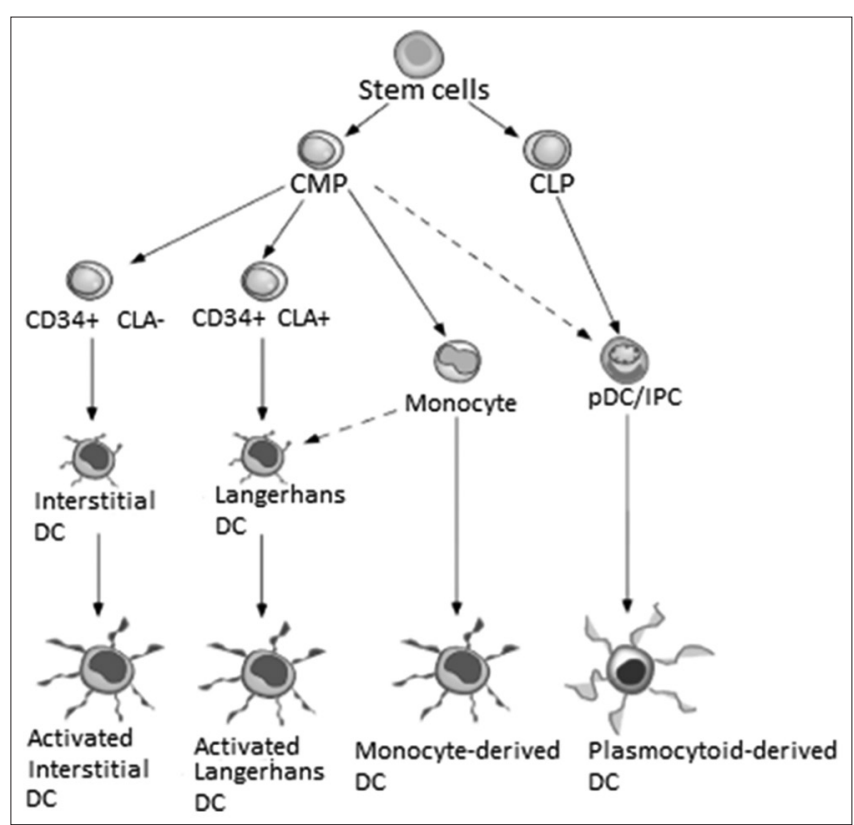

Fig. 1: Origin and development of dendritic cells

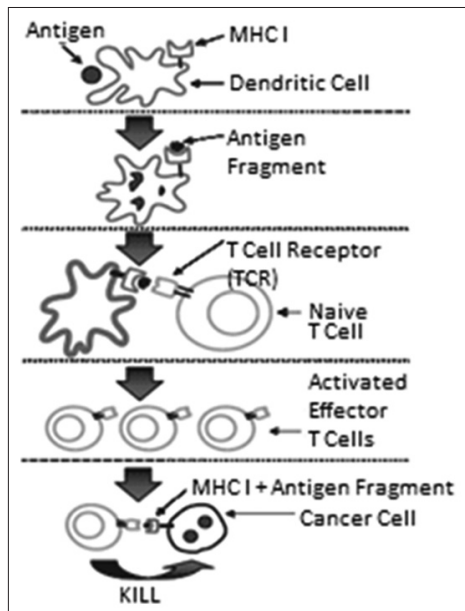

Fig. 2: Response from a dendritic cell to an activated cytotoxic T lymphocyte

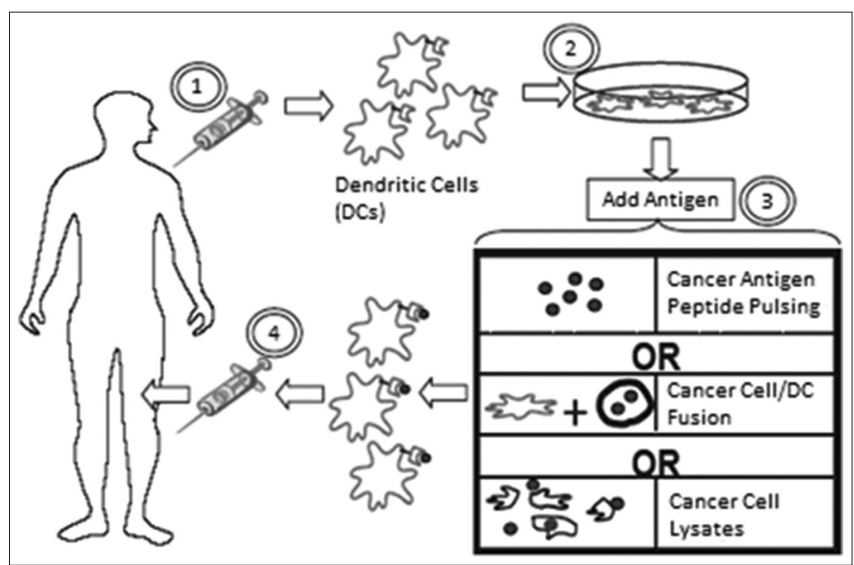

Fig. 3: The four basic steps in a dendritic cell cancer vaccine 
with cancer antigens $[67,68]$ as a potentially more effective strategy of therapeutic vaccination in cancer individuals [69]. Of particular note, DCs are important targets of cancer, and attention should be paid to the choice of DCs used in clinical studies [70]. Different types of DCs may exhibit not only a different potential in inducing antiviral immunity but also a different degree of susceptibility to cancer and the capability to transfer the virus to the target cell [71]. Thus, both preclinical and clinical studies are needed to evaluate the effectiveness of DC-based vaccines in the immunotherapy of cancer [72]. We conclude this review by emphasizing that although the possible future validation of DC-based vaccines for the immunotherapy of cancer [73] will certainly not solve the drastic needs of cancer individuals in the developing countries, [74] the progress of the research in this field will help us to identify novel and practical strategies for the in vivo targeting of the relevant cancer antigens to the right DCs [75]. All this

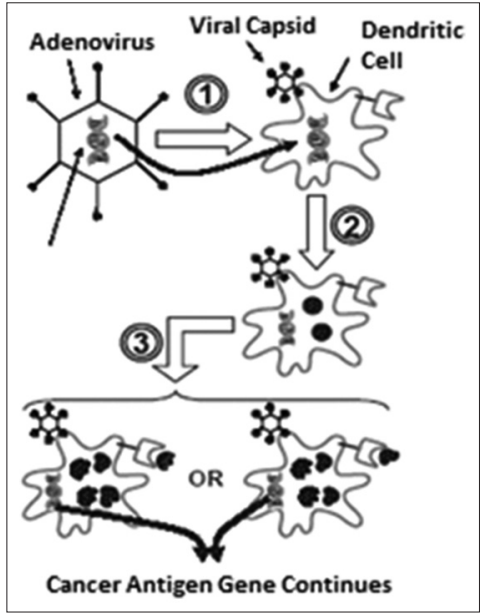

Fig. 4: Using viral gene transduction to introduce antigen genes into a DC will lead to the definition of new cost-effective immunotherapy for various types of cancer [76]

\section{CONCLUSION}

Although it is too early to determine the ultimate role for cancer vaccines, the results do provide an increasingly clear picture of the challenges that require attention. First, it will be necessary to identify from among the many strategies a few vaccines with enough promise to warrant large-scale clinical trials. This will require novel clinical trial designs and intermediate markers of activity such as immunologic assays to determine which induce the most potent antigen-specific immune responses. Recent attempts to reach a consensus on the immune assays to use and how to interpret them should simplify comparison across various studies. Second, the level of immune response detected by these assays is still fairly low. If one was to assume that the magnitude of the T-cell response necessary to clear viral infections is similar to the magnitude required to destroy tumors, then most cancer vaccines activate T-cell responses two or more orders of magnitude less than is necessary. Third, tumors possess a variety of mechanisms for evading even a high-level T-cell or antibody response. Finally, before a vaccine can be administered to patients, it will require considerable regulatory scrutiny to ensure that it is safe and effective. Although the regulatory requirements for infectious-disease vaccines have been honed over many years, the use of cellular vaccines poses new issues for the Food and Drug Administration and other regulators.

\section{AUTHORS' CONTRIBUTIONS}

Praveen Kumar Vemuri taken responsibility in the conception and design of the study. Ankitha Kunta contributed substantially in compiling literature sources and drafting the manuscript. Rishitha Challagulla has provided critical revision of the article for important intellectual content. Elizabeth Anwitha Jose has checked the references. Vijaya Lakshmi Bodiga has given final approval of the version to be published.

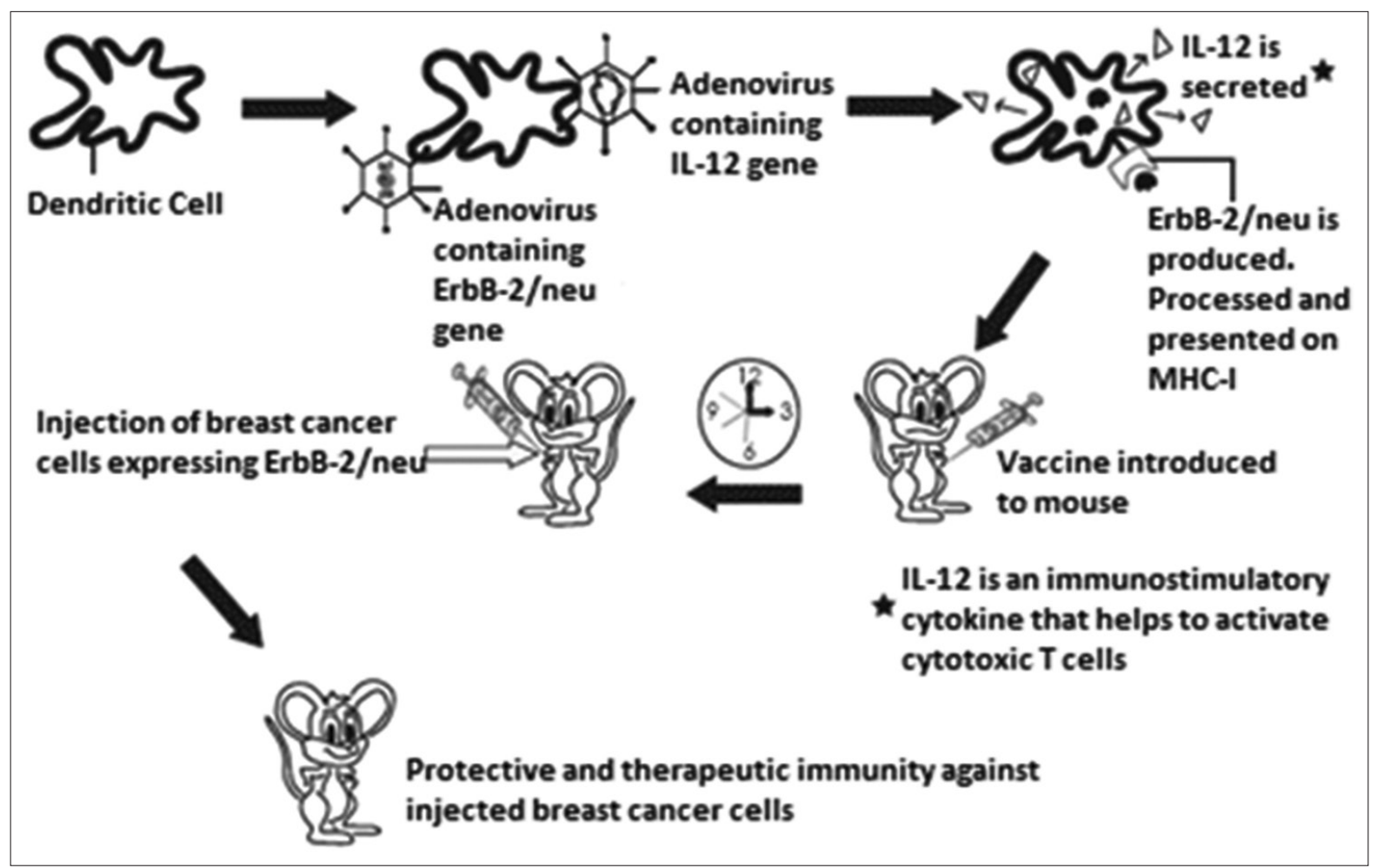

Fig. 5: Successful transduction of breast cancer antigen, ErbB-2/neu, and interleukin-12 genes into dendritic cells (DCs) before administering the DCs as a vaccine to induce protective and therapeutic immunity against injected breast cancer cells 


\section{CONFLICTS OF INTEREST}

The authors declare that there are no conflicts of interest exist among them regarding the publication of this paper.

\section{REFERENCES}

1. Bhardwaj N, Friedman SM, Cole BC, Nisanian AJ. Dendritic cells are potent antigen-presenting cells for microbial superantigens. J Exp Med 1992;175:267-73.

2. Steinman RM. The dendritic cell system and its role in immunogenicity. Annu Rev Immunol 1991;9:271-96.

3. Holt PG, Degebrodt A, O’Leary C, Krska K, Plozza T. T cell activation by antigen-presenting cells from lung tissue digests: Suppression by endogenous macrophages. Clin Exp Immunol 1985;62:586-93.

4. Palucka K, Banchereau J. Dendritic-cell-based therapeutic cancer vaccines. Immunity 2013;39:38-48

5. Kaiko GE, Horvat JC, Beagley KW, Hansbro PM. Immunological decision-making: How does the immune system decide to mount a helper T-cell response? Immunology 2008;123:326-38.

6. Théry C, Duban L, Segura E, Véron P, Lantz O, Amigorena S, et al. Indirect activation of naïve $\mathrm{CD} 4+\mathrm{T}$ cells by dendritic cell-derived exosomes. Nat Immunol 2002;3:1156-62

7. Näslund TI, Gehrmann U, Qazi KR, Karlsson MC, Gabrielsson S. Dendritic cell-derived exosomes need to activate both $\mathrm{T}$ and B cells to induce antitumor immunity. J Immunol 2013;190:2712-9.

8. Banchereau J, Steinman RM. Dendritic cells and the control of immunity. Nature 1998;392:245-52.

9. Hanna N, Fidler IJ. Role of natural killer cells in the destruction of circulating tumor emboli. J Natl Cancer Inst 1980;65:801-9.

10. Tacken PJ, de Vries IJ, Torensma R, Figdor CG. Dendritic-cell immunotherapy: From ex vivo loading to in vivo targeting. Nat Rev Immunol 2007;7:790-802.

11. Guermonprez P, Valladeau J, Zitvogel L, Théry C, Amigorena S. Antigen presentation and $\mathrm{T}$ cell stimulation by dendritic cells. Annu Rev Immunol 2002;20:621-67.

12. Liu M, Guo S, Hibbert JM, Jain V, Singh N, Wilson NO, et al. CXCL10/ IP-10 in infectious diseases pathogenesis and potential therapeutic implications. Cytokine Growth Factor Rev 2011;22:121-30.

13. Wells AD, Malkovsky M. Heat shock proteins, tumor immunogenicity and antigen presentation: An integrated view. Immunol Today 2000;21:129-32.

14. Candido KA, Shimizu K, McLaughlin JC, Kunkel R, Fuller JA, Redman BG, et al. Local administration of dendritic cells inhibits established breast tumor growth: Implications for apoptosis-inducing agents. Cancer Res 2001;61:228-36.

15. Collin M, McGovern N, Haniffa M. Human dendritic cell subsets. Immunology 2013;140:22-30.

16. Banchereau J, Palucka AK. Dendritic cells as therapeutic vaccines against cancer. Nat Rev Immunol 2005;5:296-306.

17. Palucka K, Banchereau J. Cancer immunotherapy via dendritic cells. Nat Rev Cancer 2012;12:265-77.

18. Galy A, Travis M, Cen D, Chen B. Human T, B, natural killer, and dendritic cells arise from a common bone marrow progenitor cell subset. Immunity 1995;3:459-73.

19. Sousa CR. Activation of dendritic cells: Translating innate into adaptive immunity. Curr Opin Immunol 2004;16:21-5.

20. Roncarolo MG, Levings MK, Traversari C. Differentiation of T regulatory cells by immature dendritic cells. J Exp Med 2001;193:F5-9.

21. Bachmann MF, Kopf M, Marsland BJ. Chemokines: More than just road signs. Nat Rev Immunol 2006;6:159-64.

22. Sallusto F, Lanzavecchia A. The instructive role of dendritic cells on T-cell responses. Arthritis Res 2002;4 Suppl 3:S127-32.

23. Gallucci S, Matzinger P. Danger signals: SOS to the immune system. Curr Opin Immunol 2001;13:114-9.

24. Rescigno M, Martino M, Sutherland CL, Gold MR, RicciardiCastagnoli P. Dendritic cell survival and maturation are regulated by different signaling pathways. J Exp Med 1998;188:2175-80.

25. Zlotnik A, Moore TA. Cytokine production and requirements during T-cell development. Curr Opin Immunol 1995;7:206-13.

26. Sakaguchi S, Yamaguchi T, Nomura T, Ono M. Regulatory T cells and immune tolerance. Cell 2008;133:775-87.

27. Steinman RM, Turley S, Mellman I, Inaba K. The induction of tolerance by dendritic cells that have captured apoptotic cells. J Exp Med 2000;191:411-6.

28. Hackstein H, Morelli AE, Thomson AW. Designer dendritic cells for tolerance induction: Guided not misguided missiles. Trends Immunol 2001;22:437-42

29. Rabinovich GA, Gabrilovich D, Sotomayor EM. Immunosuppressive strategies that are mediated by tumor cells. Annu Rev Immunol 2007;25:267-96.

30. Mahanty S, Hutchinson K, Agarwal S, McRae M, Rollin PE, Pulendran B, et al. Cutting edge: Impairment of dendritic cells and adaptive immunity by ebola and lassa viruses. J Immunol 2003;170:2797-801

31. Stanley MA. Progress in prophylactic and therapeutic vaccines for human papillomavirus infection. Expert Rev Vaccines 2003;2:381-9.

32. Reddy ST, Swartz MA, Hubbell JA. Targeting dendritic cells with biomaterials: Developing the next generation of vaccines. Trends Immunol 2006;27:573-9.

33. Palucka K, Banchereau J. How dendritic cells and microbes interact to elicit or subvert protective immune responses. Curr Opin Immunol 2002;14:420-31

34. Braciale TJ. Antigen processing for presentation by MHC class I molecules. Curr Opin Immunol 1992;4:59-62.

35. Kovacsovics-Bankowski M, Rock KL. A phagosome-to-cytosol pathway for exogenous antigens presented on MHC class I molecules. Science 1995;267:243-6.

36. Dudziak D, Kamphorst AO, Heidkamp GF, Buchholz VR, Trumpfheller C, et al. Differential antigen processing by dendritic cell subsets in vivo. Science 2007;315:107-11.

37. Heath WR, Belz GT, Behrens GM, Smith CM, Forehan SP, Parish IA, et al. Cross-presentation, dendritic cell subsets, and the generation of immunity to cellular antigens. Immunol Rev 2004;199:9-26.

38. Delamarre L, Holcombe H, Mellman I. Presentation of exogenous antigens on major histocompatibility complex (MHC) class I and MHC class II molecules is differentially regulated during dendritic cell maturation. J Exp Med 2003;198:111-22.

39. den Haan JM, Lehar SM, Bevan MJ. CD8+ but not CD8- dendritic cells cross-prime cytotoxic T cells in vivo. J Exp Med 2000;192:1685-96.

40. Belz GT, Carbone FR, Heath WR. Cross-presentation of antigens by dendritic cells. Crit Rev Immunol 2002;22:439-48.

41. Knutson KL, Disis ML. Tumor antigen-specific $T$ helper cells in cancer immunity and immunotherapy. Cancer Immunol Immunother 2005;54:721-8

42. Xia W, Pinto CE, Kradin RL. The antigen-presenting activities of Ia+ dendritic cells shift dynamically from lung to lymph node after an airway challenge with soluble antigen. J Exp Med 1995;181:1275-83.

43. Bousso P, Robey E. Dynamics of CD8+ T cell priming by dendritic cells in intact lymph nodes. Nat Immunol 2003;4:579-85.

44. Schuurhuis DH, Ioan-Facsinay A, Nagelkerken B, van Schip JJ, Sedlik C, Melief CJ, et al. Antigen-antibody immune complexes empower dendritic cells to efficiently prime specific CD8+ CTL responses in vivo. J Immunol 2002;168:2240-6.

45. Sad S, Marcotte R, Mosmann TR. Cytokine-induced differentiation of precursor mouse CD8+ T cells into cytotoxic CD8+ T cells secreting th1 or th2 cytokines. Immunity 1995;2:271-9.

46. Märten A, Ziske C, Schöttker B, Renoth S, Weineck S, Buttgereit P, et al. Interactions between dendritic cells and cytokine-induced killer cells lead to an activation of both populations. J Immunother 2001;24:502-10.

47. Chen L, Linsley PS, Hellström KE. Costimulation of T cells for tumor immunity. Immunol Today 1993;14:483-6.

48. Schreiber RD, Old LJ, Smyth MJ. Cancer immunoediting: Integrating immunity's roles in cancer suppression and promotion. Science 2011;331:1565-70.

49. Nestle FO, Farkas A, Conrad C. Dendritic-cell-based therapeutic vaccination against cancer. Curr Opin Immunol 2005;17:163-9.

50. Sprinzl GM, Kacani L, Schrott-Fischer A, Romani N, Thumfart WF. Dendritic cell vaccines for cancer therapy. Cancer Treat Rev 2001;27:247-55

51. Vermaelen K. Strategies to improve cancer vaccine efficacy. Front Immunol 2019;10:8

52. Condon C, Watkins SC, Celluzzi CM, Thompson K, Falo LD. DNA based immunization by in vivo transfection of dendritic cells. Nat Med 1996;2:1122

53. Chang ST, Linderman JJ, Kirschner DE. Multiple mechanisms allow mycobacterium tuberculosis to continuously inhibit MHC class IImediated antigen presentation by macrophages. Proc Natl Acad Sci U S A 2005; 102:4530-5.

54. Anguille S, Smits EL, Cools N, Goossens H, Berneman ZN, Van Tendeloo VF, et al. Short-term cultured, interleukin-15 differentiated dendritic cells have potent immunostimulatory properties. J Transl Med 
2009;7:109

55. Germain RN. MHC-dependent antigen processing and peptide presentation: Providing ligands for $\mathrm{T}$ lymphocyte activation. Cell 1994; 76:287-99.

56. Larsson M, Fonteneau JF, Bhardwaj N. Dendritic cells resurrect antigens from dead cells. Trends Immunol 2001;22:141-8

57. Kay MA, Glorioso JC, Naldini L. Viral vectors for gene therapy: The art of turning infectious agents into vehicles of therapeutics. Nat Med 2001;7:33-40

58. Hudu SA, Shinkafi SH, Umar S. An overview of recombinant vaccine technology, adjuvants and vaccine delivery methods. Int J Pharm Pharm Sci 2016;8:19-24.

59. Rea D, Johnson ME, Havenga MJ, Melief CJ, Offringa R. Strategies for improved antigen delivery into dendritic cells. Trends Mol Med 2001;7:91-4

60. Vorburger SA, Hunt KK. Adenoviral gene therapy. Oncologist 2002;7:46-59.

61. Lipford GB, Sparwasser T, Bauer M, Zimmermann S, Koch ES, Heeg $\mathrm{K}$, et al. Immunostimulatory DNA: Sequence-dependent production of potentially harmful or useful cytokines. Eur J Immunol 1997;27:3420-6.

62. Fioretti D, Iurescia S, Fazio VM, Rinaldi M. DNA vaccines: Developing new strategies against cancer. J Biomed Biotechnol 2010;2010:174378.

63. Jinushi M, Tahara H. Cytokine gene-mediated immunotherapy: Current status and future perspectives. Cancer Sci 2009;100:1389-96.

64. Giacomini E, Iona E, Ferroni L, Miettinen M, Fattorini L, Orefici G, et al. Infection of human macrophages and dendritic cells with mycobacterium tuberculosis induces a differential cytokine gene expression that modulates T cell response. J Immunol 2001;166:7033-41.

65. Holla SN, Nayak V, Bairy KL, Tripathy A, Holla NS. Her-2 gene, receptors and drug target: A systematic review. Int J Pharm Pharm Sci 2016;8:4-9.

66. Bodiga VL, Thokala S, Vemuri PK, Bodiga S. Zinc pyrithione inhibits caspase-3 activity, promotes erbB1-erbB2 heterodimerization and suppresses erbB2 downregulation in cardiomyocytes subjected to ischemia/reperfusion. J Inorg Biochem 2015;153:49-59.

67. Ebert O, Harbaran S, Shinozaki K, Woo SL. Systemic therapy of experimental breast cancer metastases by mutant vesicular stomatitis virus in immune-competent mice. Cancer Gene Ther 2005; 12:350-8.

68. Lee SC, Srivastava RM, López-Albaitero A, Ferrone S, Ferris RL.
Natural killer (NK): Dendritic cell (DC) cross talk induced by therapeutic monoclonal antibody triggers tumor antigen-specific $\mathrm{T}$ cell immunity. Immunol Res 2011;50:248-54

69. Degli-Esposti MA, Smyth MJ. Close encounters of different kinds: Dendritic cells and NK cells take centre stage. Nat Rev Immunol 2005;5:112-24

70. Przetak M, Chow J, Cheng H, Rose J, Hawkins LD, Ishizaka ST, et al. Novel synthetic LPS receptor agonists boost systemic and mucosal antibody responses in mice. Vaccine 2003;21:961-70.

71. Vidal V, Dewulf J, Bahr GM. Enhanced maturation and functional capacity of monocyte-derived immature dendritic cells by the synthetic immunomodulator murabutide. Immunology 2001;103:479-87.

72. Zamai L, Ponti C, Mirandola P, Gobbi G, Papa S, Galeotti L, et al. NK cells and cancer. J Immunol 2007;178:4011-6.

73. Rinaldo Jr CR, Piazza P. Virus infection of dendritic cells: portal for host invasion and host defense. Trends Microbiol 2004;12:337-45.

74. Boczkowski D, Nair SK, Snyder D, Gilboa E. Dendritic cells pulsed with RNA are potent antigen-presenting cells in vitro and in vivo. J Exp Med 1996;184:465-72

75. Su Z, Dannull J, Heiser A, Yancey D, Pruitt S, Madden J, et al. Immunological and clinical responses in metastatic renal cancer patients vaccinated with tumor RNA-transfected dendritic cells. Cancer Res 2003;63:2127-33.

76. Brody JD, Engleman EG. DC-based cancer vaccines: Lessons from clinical trials. Cytotherapy 2004;6:122-7.

77. Wu L, KewalRamani VN. Dendritic-cell interactions with HIV: Infection and viral dissemination. Nat Rev Immunol 2006;6:859-68.

78. Gelao L, Criscitiello C, Esposito A, De Laurentiis M, Fumagalli L, Locatelli MA, et al. Dendritic cell-based vaccines: Clinical applications in breast cancer. Immunotherapy 2014;6:349-60.

79. Gilboa E. DC-based cancer vaccines. J Clin Invest 2007;117:1195-203.

80. Brandts $\mathrm{CH}$. Innovating the outreach of comprehensive cancer centers. Mol Oncol 2019;13:619-23.

81. Finn OJ. The dawn of vaccines for cancer prevention. Nat Rev Immunol 2018;18:183-94.

82. Tannock IF, Hickman JA. Limits to personalized cancer medicine. N Engl J Med 2016;375:1289-94. 